\title{
Extending the Margin of Safety Concept to Brick-and-Mortar Retailing in India (MoSR-b)
}

\author{
H. R. Ganesha ${ }^{1} \&$ P. S. Aithal ${ }^{2}$ \\ ${ }^{1}$ Chief Executive Officer - Consulting Division, Gramss Retail Trading Private Limited, \\ Bengaluru - 560078, India and Post-Doctoral Research Fellow, College of Management \& \\ Commerce, Srinivas University, Mangalore - 575001, India. \\ OrcidID: 0000-0002-5878-8844; E-mail: hrganesha@yahoo.co.in \\ ${ }^{2}$ Vice Chancellor, Srinivas University, Mangalore - 575001, India. \\ OrcidID: 0000-0002-4691-8736; E-mail: psaithal@,gmail.com
}

Area of the Paper: Business Management.

Type of the Paper: Conceptual Research.

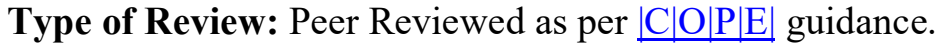

Indexed In: OpenAIRE.

DOI: http://doi.org/10.5281/zenodo.4033186.

Google Scholar Citation: IJCSBE.

\section{How to Cite this Paper:}

Ganesha, H. R., \& Aithal, P. S. (2020). Extending the Margin of Safety Concept to Brick-andMortar Retailing in India (MoSR-b). International Journal of Case Studies in Business, IT, and Education (IJCSBE), 4(2), 117-131. DOI: http://doi.org/10.5281/zenodo.4033186.

International Journal of Case Studies in Business, IT and Education (IJCSBE) A Refereed International Journal of Srinivas University, India.

(C) With Authors.

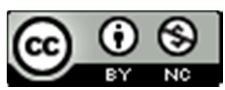

This work is licensed under a Creative Commons Attribution Non-Commercial 4.0 International License subject to proper citation to the publication source of the work.

Disclaimer: The scholarly papers as reviewed and published by the Srinivas Publications (S.P.), India are the views and opinions of their respective authors and are not the views or opinions of the S.P. The S.P. disclaims of any harm or loss caused due to the published content to any party. 


\title{
Extending the Margin of Safety Concept to Brick-and- Mortar Retailing in India (MoSR-b)
}

\author{
H. R. Ganesha ${ }^{1}$ \& P. S. Aithal ${ }^{2}$ \\ ${ }^{1}$ Chief Executive Officer - Consulting Division, Gramss Retail Trading Private Limited, \\ Bengaluru - 560078, India and Post-Doctoral Research Fellow, College of Management \& \\ Commerce, Srinivas University, Mangalore - 575001, India. \\ OrcidID: 0000-0002-5878-8844; E-mail: hrganesha@yahoo.co.in \\ ${ }^{2}$ Vice Chancellor, Srinivas University, Mangalore - 575001, India. \\ OrcidID: 0000-0002-4691-8736; E-mail: psaithal@gmail.com
}

\begin{abstract}
The Margin of Safety (MoS) concept is predominantly used in Investment, Accounting, Structural Engineering, and Medicine domains of study. Irrespective of the domain of study the MoS concept plays a crucial role in accounting for any uncertainty. We could simply assert that the concept of MoS is relevant and necessary for brick-and-mortar (B\&M) retailers in India. In the context of B\&M retailing we define $\mathrm{MoS}$ as the level of immunity developed by a B\&M retailer over unexpected short-term market disruptions such as (a) the shutdown of specific locality forced by political parties or other organizations; (b) entry of new competitors in a catchment; (c) lucrative offers floated by competitors in the catchment, etc., and long-term market disruptions such as (a) lockdown of a locality owing to public health safety measures (for instance, Covid-19 lockdown); (b) shutdown of a locality for civil and infrastructural development works; (c) entry of new retailing formats (for instance, Online stores), etc. In this paper, we have developed a conceptual framework (MoSR-b) that would enable B\&M retailers in India to develop a margin of safety to overcome short and long-term market disruptions and uncertainties. In developing the MoSR-b, we have adopted recommendations from existing literature that are known and suitable for Indian retailing in the context of MoS, in addition to identifying (i) new elements capable of developing the $\mathrm{MoS}$, and (ii) borrowing insights from multiple empirical and qualitative studies, field experiments, and evaluation of consumer-level transactions. Instead of limiting the scope of MoS to just a few financial aspects of the business, our MoSR-b framework extends the scope of $\mathrm{MoS}$ in becoming the core of achieving business operational efficiencies in addition to providing early indications on the immunity level of a retail organization against short and long-term market disruptions.
\end{abstract}

Keywords: Indian Retail, Brick-and-Mortar Retail, Margin of Safety, Bandh, Lockdown, Shutdown, Market Disruption, Pandemic, COVID-19, Immunity to Market Disruptions.

\section{INTRODUCTION :}

1.1 Margin of Safety: 86 years ago, Graham and Dodd were the first to coin the term a Margin of Safety (MoS) [1]. In the Accounting discipline, MoS is simply, how much sales/revenue level can fall before a business reaches its break-even point. Later in the year 1991, Klarman defined MoS as 'investing at considerable discounts from underlying value, an individual provides himself or herself room for imprecision, bad luck, or analytical error (i.e., a "margin of safety") while avoiding sizable losses'. He also emphasizes, 'to achieve long-term success over many financial market and economic cycles, observing a few rules is not enough as too many things change too quickly in the investment world for that approach to succeed and hence, it is necessary instead to understand the rationale behind the rules to appreciate why they work when they do and don't when they don't' $[2]$. 
In the Structural Engineering domain, MoS describes 'what additional load beyond the design load a part can withstand before failing, in other words, this is a measure of excess capacity, i.e., if the margin is 0 , the part will not take any additional load before it fails, if it is negative the part will fail before reaching its design load in service, if the margin is 1 , it can withstand one additional load of equal force to the maximum load it was designed to support (i.e. twice the design load)' [3-5]. In the Medicine domain, MoS that is also referred to as Certain Safety Factor, 'is the ratio of the lethal dose to $1 \%$ of the population to the effective dose to $99 \%$ of the population' [6]. Irrespective of the domain of study the essence of the MoS concept plays a crucial role in accounting for any uncertainty. We could simply assert that the concept of MoS is relevant for brick-and-mortar (B\&M) retailing in India. In the context of B\&M retailing we define MoS as the level of immunity developed by a $B \& M$ retailer over unexpected short-term disruptions in the market such as i) shutdown of specific locality forced by political parties or other organizations; ii) entry of new competitors in a catchment; iii) lucrative offers floated by competitors in the catchment and long-term market disruption such as i) lockdown of a locality owing to public health safety measures (for instance, Covid-19 lockdown); ii) shutdown of a locality for civil and infrastructure developmental works; iii) entry of new retailing formats (for instance, Online stores).

1.2 Importance of MoS: A majority of finance/accounting/audit personnel use the concept of MoS to mathematically derive a sales/revenue target that would create MoS for the business assuming they cannot control the costs that are fixed/recurring thereby limiting the scope of $\mathrm{MoS}$ to certain financial aspects of the business. We determinedly believe the concept of MoS must become the core of achieving business operational efficiencies in addition to providing early indications on the immunity level of a retail organization against short and long-term market disruptions. The concept of MoS becomes furthermore crucial for B\&M retailing in India owing to the sheer market size and the forecast growth. It is reported that the organized retailing in India that was 12 percent of the overall retail market in the year 2017, is expected to increase to 25 percent by the year 2021 [7]. The overall market size of the Indian retail industry that was 950 billion USD in the year 2018 of which 97 percent was from B\&M retailing is forecast to reach 1.75 trillion USD by the year 2026. In other words, at present, about 10 percent of the nominal gross domestic product of India is contributed by the retail industry in addition to accounting for 8 percent of employment [8].

1.3 Overview of the Paper: In this paper, we explain how an MoS concept could be institutionalized to play an important role in achieving operational efficiencies in addition to acting as a tool to measure investment security for B\&M retailers in India. In Section 2, we explain a conceptual framework that is developed based on existing literature in addition to empirical and qualitative studies carried by us relevant in the Indian context. In Section 3, we compare our conceptual framework with existing B\&M retailing practices in India. And, in addition to stating limitations; the scope for further development of the framework; suggestions to B\&M retailers in India; we shall summarise MoSR-b and conclude in Section 4.

\section{CONCEPTUAL FRAMEWORK OF MoSR-b :}

The concept of an MoS must become one of the key determinants while deciding on the ideal Marketing Mix of a B\&M retailing organization across all the "4P's". The Marketing Mix concept in literature can be traced back to the 1940s and can be attributed to Borden as the first one to mention such a concept in general [9]. Later in the 1960s, McCarthy gave a framework to basic elements of Marketing Mix which are globally known as "4P's" of Marketing Mix of which, the first one being 'Product', the second one being 'Price', the third one being 'Promotion' and the fourth one being 'Place'[10]. Many researchers through their studies have criticized the "4P's" Marketing Mix concept arguing that the framework has shortcomings and only suitable for traditional marketing strategies [11 to 13]. However, many studies have provided their consensus that "4P's" framework of Marketing Mix is a powerful tool in marketing even today and they have been used by the majority of management practitioners and researchers around the world [14]. Studies across domains such as Marketing Theory, Relationship Marketing, Services Marketing, Retail Marketing, and Industrial Marketing, whether or not agreeing to the "4P's" framework have continuously suggested additional elements to be part of the original "4P's" framework and proposition of Marketing Mix of which few key elements are; Political Power and Public Opinion Formulation [15]; Customers, Competitors and 
Corporation [16]; Capabilities [17]; Mapping of Marketing Mix Elements [18]; Services and Staff [19]; Value, Viability, Variety, Volume and Virtue [20]; Performance, Penalty, Perceptions and Process [21]; Marketing Triad Marketer, Employee and Customer [22]; Customer Orientation, Customer Needs, Convenience, Customer's Cost and Communication [23]; Product Extras, Reinforcing Promotions, Sales-Force Connections, Specialized Distribution and Post-Purchase Communication [24]; Relationships, Network, and Interaction [25]; Relationship Marketing [26]; Personalisation, Personnel, Physical Assets and Procedures [27]; Communication, Customisation, Collaboration and Clairvoyance [28]; Relationships, Neo-Relationship and Networking [29]; Participants, Physical Evidence and Process [30 to 31]; Concept Mix, Cost Mix, Channels Mix, Communication Mix [32]; Intangibility, Inseparability, Perishability and Variability of Services [33]; Differentiation, Customer Contact and Unique Vision on Quality Parameter [34]; Personnel [35]; Communication and Distribution [36]; Publications [37]; Relevance, Response, Relationships and Results [38]; Actors, Audience, Setting and Performance [39]; Brand, Packaging and Relationships [40]; Logistic Concept and Commercial Concept [41]; Assortment, Shop Presentation, Price Policy, Personnel [42]; Store Location, Store Positioning, Store Image, Physical Environment and Retail Service [43]; Data Base, Interaction and Network [44]; Target Market, Product Assortment cum Procurement, Services cum Store Atmosphere, Price Decision and Place Decision [45]; Quality and Degree of interdependence among business to business organisations [46]; International Elements [47]; Customer Service, Teamwork, Service Quality and Service Excellence [48]; Relationships and Networks Management [49]; Co-Design cum Production, Transparent Pricing, Direct Contacts with Customers, Control of the Customer Interaction [50].

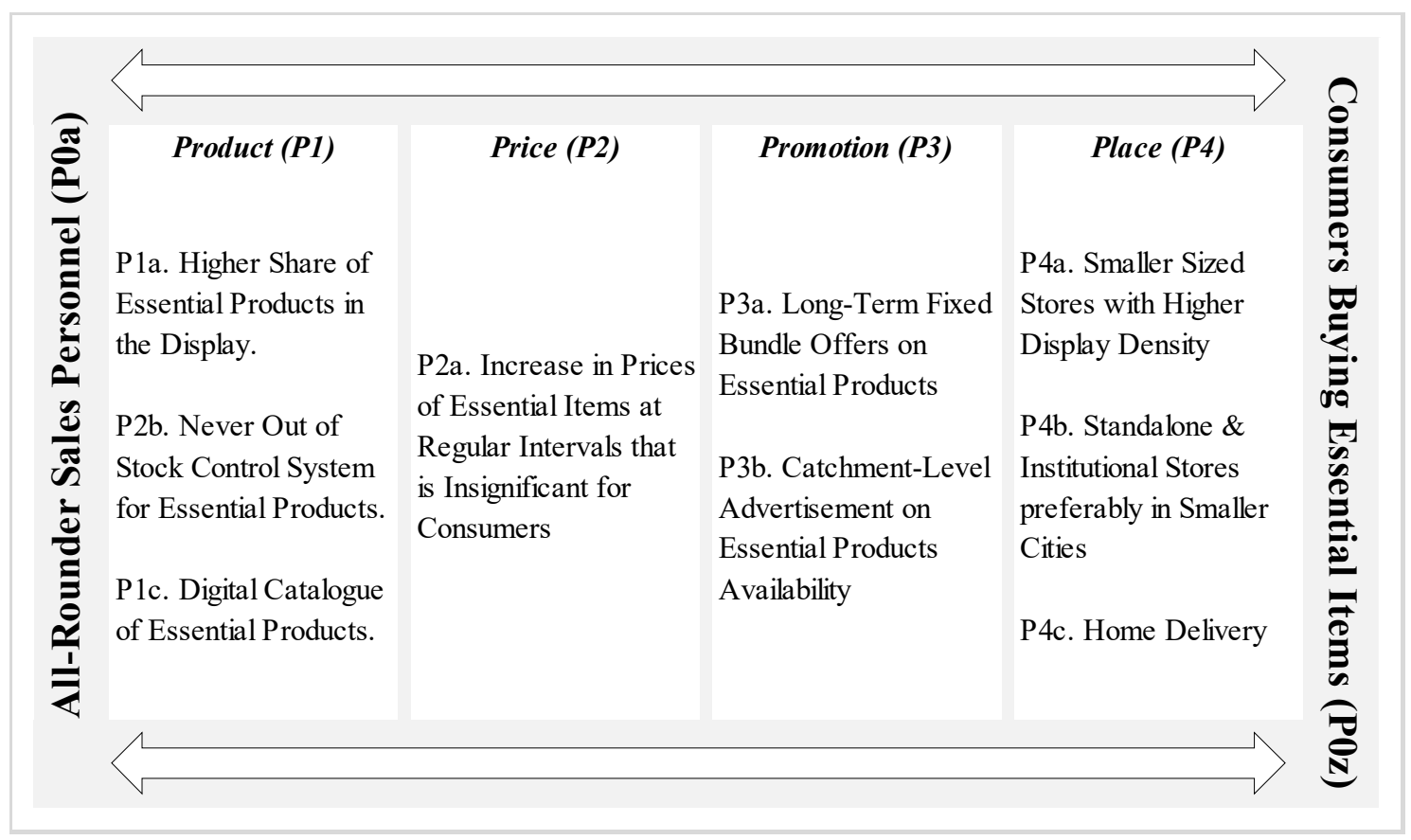

Fig. 1: MoSR-b Conceptual Framework

We determinedly believe that all the new elements suggested by various studies were inherent elements within "4P's" proposition which was originally framed by McCarthy sixty years ago and therefore through this research study we intend to customize the original "4P's of Marketing Mix framework to suit B\&M retailing in India which could help them create sufficient MoS that shall develop stronger immunity over short and long-term market disruptions. The approach we have taken in developing a conceptual framework of MoS for B\&M retailing in India (MoSR-b) as represented in Figure 1, is to formulate a structure that enables us to integrate possible elements across all the "4P's' of Marketing Mix proposition. We will now explain the MoSR-b framework for every 'P' of the Marketing Mix in addition to explaining how these are interlinked in creating a possible MoS. 


\subsection{Product (P1)}

Each product in a store belongs to different categories and each category plays a different role for the retailer or retail store. The retailer needs to clearly understand these varied roles of different categories concerning their key deliverables to the overall business. It is recommended, that, "the fundamental principle of merchandise management involves identification of the key categories of merchandise (say yellow, orange and white goods) for any retail store; ascertain their purpose (say, crowd puller, staple, and impulse) and subsequently develop the procurement as well as the delivery plan along with the planogram of the stores under consideration' [51-52]. Every category/brand/product has a role to play concerning consumer needs and the retailer's business goals. Based on demand-side characteristics all the categories/brands/products in the assortment must be classified into Essentials and Non-essentials. The essential category consists of products that are needed by the consumers at least once a month or more frequently and most importantly, this categorization must not be dependent on any supply-side constraints [53]. We have found that the essentials category despite occupying the lowest store area, having the lowest average selling price products in the assortment, and generating the lowest average transaction values deliver the highest category profits if focussed by the retailer. The essentials category by its nature is required by consumers more frequently than other categories and if focussed and pushed well, the category is capable of increasing the number of repeat consumers thereby enhancing the higher consumer retention rate for the store. If the B\&M retailer considers the store's absolute top-line value as the key indicator of judging the best category for a store, focussing on the Hardlines category is ideal. If the retailer considers the absolute store's profit value as the key indicator of judging the best category for a store, pushing the Essentials category is ideal. If the retailer considers moderate store profits as the key indicator of judging the best category for a store, pushing the Softline category is ideal. And if the retailer is interested in overall retail performance with consistent growth, sustainable profits, and a higher consumer retention rate then a rational mix of each of these categories is an ideal solution [54]. Moreover, we have also found a significant correlation (0.962) between the number of bills/invoices carrying essential products and the consumer repeat store visit rate with a strong determination (0.925 with ANOVA Sig. Value 0.000) [55].

All these findings denote that the Essentials category of products in a store in addition to ensuring consistent repeat consumer visits to the store enhances the probability of consumers intent to patronage with the store irrespective of the short and long-term market disruptions. Thus, under the first group of Marketing Mix, i.e., Product (P1), identification and categorization of products into essentials becomes the core of our conceptual framework MoSR-b. The proposed framework recommends the B\&M retailers i) to allocate larger and prominent space for essential products $(\mathrm{P} 1 \mathrm{a})$, ii) ensure any product that is categorized as essentials is never out of stock (P1b), and iii) equip sales personnel and consumers with a digital catalog of all the essentials products (P1c). All these elements of MoSR-b play an important role in creating a positive and strong perception in consumer's minds about a store as being one of their essential stores that also carry a wider assortment of non-essential products.

\subsection{Price (P2)}

Most of the studies on price changes have focused on price decreases and its impact on consumer's re-purchase intentions. In one of the studies by Homburg et. al. that investigates the effects of price increases at an individual level, argue that consumers' reactions to price increases concerning repurchase intentions are strongly driven by two factors such as i) the magnitude of the price increase and ii) the perceived fairness of the motive for the price increase. In this context, the authors examine the role of consumer satisfaction in influencing the impact of these two variables on the re-purchase intentions post-price increase. Their findings reveal that as satisfaction increases, the negative impact of the magnitude of a price increase is weakened. Furthermore, the results suggest that satisfaction moderates the impact of perceived motive fairness. The authors also find that the level of satisfaction can influence the valence of the perceived motives in response to a price increase [56].

It is a universally known phenomenon that the essential products are supposed to be priced competitively which in other ways puts pressure on retailers to settle for lower intake margin levels thereby distracting them from focussing on essential products. Under the second group of Marketing Mix, i.e., Price (P2), we strongly recommend B\&M retailers to regularly increase the prices of 
essential products and ensure the level of such increase is insignificant in magnitude for any consumer (P2a). This is another way that enhances the category level earning potential without affecting consumer's re-purchase intention.

\subsection{Promotion (P3)}

It is practically impossible to change consumer's perspective towards a discount in favor of the B\&M store as the same is widely influenced by a paradigm shift in the evolution of various modern retailing formats available now to consumers to buy required products especially Online stores. It was evident from empirical research that the $\mathrm{B} \& \mathrm{M}$ retailers will no more be able to convert store walk-ins into transactions unless the discount is one of the key components of their selling proposition. Multiple short and long-term experiments reveal that the discounts if offered to select consumers on select product/category, could (a) attract only relevant consumers who were planning to purchase these products, (b) distract consumers for whom the product/category on discount offer is either irrelevant or already being bought, (c) create a perception in consumers mind about discount levels available at B\&M store higher than that of an online store regularly, (d) negate the loss or reduced gross earnings in the discounted product/category through regular sales from non-discounted products/categories, and thereby (i) positively impacting the overall store-level profits and (ii) creating a sustainable competitive edge with online stores and other competitors over the discount component. It is also very important that (a) how does the sales personnel who is dealing with the consumer directly having real-time insights about consumer's intent, needs, and attitude towards a particular purchase activity communicate available discount offers to consumers with confidence? (b) does he/she believe in a particular discount offer? and (c) can he/she convince the consumer about the benefits of discount offers which are not real-time?. In addition to retailer's understanding of existing consumer base, purchase history, purchase behavior, response to different types of promotions, life-stage needs, product/category usage frequencies, levels of discounts previously offered, the decision to offer a relevant discount to the consumer in real-time is appropriate only when the sales personnel is empowered to customize it [57-60].

All these findings denote that it is all about understanding the role of every product/category and consumers concerning the overall business goal of the retailing format and applying different discounting methods concerning prevailing competition as far as the discount component is concerned. Under the third group of Marketing Mix, i.e., Promotion (P3), we strongly recommend $\mathrm{B} \& \mathrm{M}$ retailers adopt an integrated discounting framework that gives clear guidelines in its application and in a way reduces the implicit complexity of the discounting phenomenon as a whole [61]. MoSR-b suggests B\&M retailers adopt a consistent, long-term, and fixed offer that is bundled with many essential products (P3a) in addition to allocating a significant proportion of catchmentlevel advertising activities towards creating awareness about the availability of essential products in the store $(\mathrm{P} 3 \mathrm{~b})$.

\subsection{Place (P4)}

In most cases, the bigger the store size higher the rent, overheads, maintenance, sales personnel, and all of these together contribute to the majority of retailing fixed costs. Except for rent most of these cost factors usually vary in proportion to the store size across all locations within a country, whereas rent is not, which in addition to store size, varies according to location type such as a mall, highstreet, institutional, etc and type of city such as Tier-1, Tier-2, and Tier-3, etc. An experiment of attempting to reduce the store size shows that it is possible to improve overall store profitability without any negative impact on the store revenue which is one of the biggest concerns for B\&M retailers whenever they think of store size reduction. Moreover, we have found an insignificant correlation (0.233) between the number of bills/invoices generated by a store and the store size with a poor determination (0.036 with a 2-tailed Sig. Value 0.000), which in turn proves the fact that the bigger the store does not guarantee higher consumer walk-ins into a store thereby yielding higher revenue and profit. We do not have any standard formula to arrive at an ideal store size for every location. Retailers need to continually experiment with different store sizes across different types of locations and derive an optimal store size for each location type. Any opportunity which prompt retailer to reduce the store size must be used for such experimentations and the learnings to be applied on the new stores which are in the expansion plan along with trying to apply the learnings on the existing stores. It is not just about reducing the store size and expect reduced costs, what is very 
important is that how does one ensure the display standards, store layout, and overall store image is being maintained even after store size reduction, else this could lead to other consumer perception, retailer/brand image, and store-image related issues which bear long-term negative impact [62].

In one of our empirical studies that intended to understand the best location for B\&M retailing in India, we have found a significant association between the type of store location and overall store profitability. The majority of stores located in a Shopping Mall deliver significantly lesser overall store profits despite attracting consumers who spend higher than the consumer spending in the Standalone-High Street and Institutional stores. Even though the average total area (an area which includes common area loading and considered for rent calculation by the property management) is similar between Standalone-High Street and Shopping Mall stores, the revenue generated by Shopping Mall stores is moderately higher with significantly lesser profit in comparison to Standalone-High Street stores. Interestingly we found that the Institutional stores with significantly lesser (78 percent) store area deliver the highest absolute overall store profits despite generating significantly lesser absolute sales/revenue in comparison to the stores in Standalone-High Street and Shopping Mall locations. Standalone-High Street stores indeed have shown that, among all the types of store locations, they can acquire a higher number of new consumers, retain a higher number of existing consumers, generate higher revenue, and moderate overall store profits [63].

It is reported that by the year 2030, urban agglomerations in India could lead to a) an increase in the middle-class consumer segment by 3 times compared to the year 2010 which was at 22 million, b) an increase in the number of people living in the urban cities to 590 million, and most importantly c) an increase in cities with more than one million population to 68 [64]. India is one of the most soughtafter countries for retailing opportunities globally, mainly because of the higher population consisting of the relatively younger population and higher penetration of internet users. Furthermore, despite India being dominantly represented by Tier-2, Tier-3, and Tier-4 cities are also witnessing rapid expansion of national and international brands/companies such as Housing, Automobiles, IT, Banking, and most importantly B\&M Retail Stores into these cities owing to an exponential growth in the urbanization of Tier-2 and Tier-3 cities post-economic liberation, Government's interest and plans for improving basic infrastructure at Tier-2 and Tier-3 cities, relatively cheaper real estate, and most importantly steadily increasing disposable income level of consumers in Tier-2 and Tier-3 cities. These developments and numbers are clear indicators of upcoming changes that are expected in the way consumers will behave while choosing retail stores to fulfill their product needs. Corroborating with this report one of our empirical studies in which we analyzed twelve months' actual sales data vis-a-vis twenty price-bands across Tier-1, Tier-2, and Tier-3 city stores of a select retailer in India, we have found that the belief of B\&M retailers in India i.e., larger the city higher the affordability of consumers towards higher-priced products and smaller the city lesser the affordability is merely a misconception and empirically unsupported. Consumers evaluate multi-location, national, and international retailers on their principal price positioning and then walk-in into the store belonging to such retailers in their city irrespective of city type in which they live only if the price positioning of the retail store matches with their affordability levels. The consumer does not expect a multi-location, national, and international retailer to adjust their price/product/brand assortment concerning city type and price, consumers expect such retailers to offer price/products/brands/categories assortment evenly across Tier-1, Tier-2, and Tier-3 cities. Most of the retailers fail to meet such expectations of consumers especially in Tier- 2 and Tier- 3 cities owing to their strong belief/misconception that consumers in smaller cities cannot afford to buy higherpriced products/brands/categories. Results have also indicated that there is no significant variance in the contribution of different price-bands vis-a-vis overall bills/invoices and revenue being generated by stores across Tier-1, Tier-2, and Tier-3 cities for a retailer who runs all these stores under a single store brand name [65].

Such insights gained from empirical studies denote that the store size, location, and the size of the city play an important role as far as B\&M retailer's financial safety is concerned. Under the last and fourth group of Marketing Mix, i.e., Place (P4), we strongly recommend B\&M retailers adopt an intelligent and well-calculated mixture of store size, store location, and the city. MoSR-b suggests B\&M retailers giving significantly higher weightage to i) having smaller sized stores that are capable of holding optimal inventory achieved through the innovative fixture and store layout planning $(\mathrm{P} 4 \mathrm{a})$; 
ii) opening stores that are Standalone in a high-street location or inside a designated shopping area in larger campuses, tech parks, resorts, hospitals, and apartments which are also known as Institutional stores ( $\mathrm{P} 4 \mathrm{~b})$. In addition to $\mathrm{P} 4 \mathrm{a}$ and $\mathrm{P} 4 \mathrm{~b}$, it is inevitable for $\mathrm{B} \& \mathrm{M}$ retailers to practice Home Delivery $(\mathrm{P} 4 \mathrm{c})$ regularly to create a strong perception in consumer's minds that the essential products (for which they have been provided with a digital catalog by the store) can be easily purchased from $\mathrm{B} \& \mathrm{M}$ stores irrespective of any short and long-term shutdowns and lockdowns in the locality. Unorganized B\&M retailers in India who hold a significant portion of the market share follow this ideology even today and can be attributed to their continued services to their existing consumers despite their stores being shut during COVID-19 lockdowns [66].

\subsection{Integration of Marketing Mix (P0)}

We strongly believe that any action taken across any of the "4P's" in isolation would not yield expected results. Inevitably B\&M retailers must integrate all the "4P's" of a store with Sales Personnel and Consumers through well-defined processes systematically. Undoubtedly a majority of retailers globally agree that the higher the consumer repeat visit rate to stores, the higher the probability of store profitability, and most importantly better unit economics across the business. The question is, are all the sales personnel in a store capable of developing a high-level of patronage with the store in consumer's minds concerning repeat store visit intention?. The answer is a 'big no'. It is evident that this is possible only when a sales personnel has higher levels of consumer orientation that is achievable through i) inputs-driven performance measures [67], ii) need-based sales pitch [68], iii) systematic empowerment of sales personnel [53] [69]; iv) a sufficient number of sales personnel in the store [70]; v) continuous efforts to develop all-rounder sales personnel through training [71]; vi) store operations-oriented organizational structure [72], and most importantly vii) adopting rational sales personnel attrition control and retention framework [73]. It is also imperative for B\&M retailers to adopt appropriate consumer communication tactics that create a positive perception and highlevels of store patronage in consumer's minds [74].

Such insights gained from empirical studies recommend B\&M retailers to be cognizant of the fact that in addition to having the most competitive " $4 \mathrm{P}$ ' $\mathrm{s}$ " proposition, the only person who makes a big difference in converting all the store walk-ins into satisfied consumers of a store is the Sales Personnel who can play an important role as far as B\&M retailer's MoS is concerned. Under the integration group of Marketing Mix, i.e., People and Processes (P0), MoSR-b suggests B\&M retailers giving significantly higher weightage i) to develop, motivate, and retain all-rounder sales personnel ( $\mathrm{P} 0 \mathrm{a})$, and ii) to consumers buying essential products while designing promotional/communication strategies $(\mathrm{P} 0 \mathrm{z})$.

In summary, the MoSR-b recommends B\&M retailers in India to give significantly higher weightage to essential products across " $4 P$ 's" of their Marketing Mix that is holistically practiced by sales personnel and communicated to consumers who buy essential products from the store.

\section{EXISTING PRACTICE VS. MoSR-b :}

In Tables 1 to 5, we have captured the attitude and existing practices of a majority of organized B\&M retailers in India across P1, P2, P3, P4, and P0 vis-à-vis the proposed MoSR-b framework. We have noticed that the majority of elements that are required and play an important role in developing MoS were either ignored by the retailer or were unknown. It is evident that during recent long-duration COVID-19 lockdown the most affected B\&M retailers were the ones whose attitude and practice was exactly opposite to that of the proposed MoSR-b framework. For instance, the most affected were the ones i) whose merchandise assortment was skewed towards non-essentials products; ii) having a higher proportion of store count in Shopping Mall locations and Tier-1 cities; iii) with a higher number of specialized sales personnel; iv) with the higher number of sales personnel practicing lower-levels of consumer orientation; v) failing to adopt home-delivery practices earlier; vi) practicing non-store elements based advertising and consumer communication tactics. Simply, a majority of such retailers were only left with mobile numbers of shoppers (not consumers! [69]) linked to previous purchase history to sit at home, analyze using the latest data science tools, and nothing more than that. 
Table 1: Comparing existing practice of B\&M retailers in the $\mathbf{P 1}$ group vis-à-vis proposed MoSR-b Existing Practice MoSR-b

Focus on Non-Essential products Focus on Essential products

Essential Products Yield Lower Gross Margin $\%$

Allocate Larger Space to Non-Essential

Products

Essential Products Mediate Higher Overall Store Profitability

Essential Products Pull-Down Average Essential Products Push-Up Average Consumer Transaction Values Lifetime Value

Consumer's Repeat Store Visit Intention is Higher if Overall Service Quality is Good

Digital Catalog is Required for High-Priced Products

Consumer's Awareness Level of their Needs is Higher than the Sales Personnel

Consumer's Repeat Store Visit Intention is Significantly Determined by Essential Category Mix

Digital Catalog is Necessary for Essential Products Irrespective of the Price

Consumer's Awareness Level of their Needs is Lower than the Sales Personnel

Consumer's Awareness Level of Products Consumer's Awareness Level of Products Availability is Higher than the Sales Personnel

Availability is Lower than the Sales Personnel

Table 2: Comparing existing practice of B\&M retailers in the $\mathbf{P 2}$ group vis-à-vis proposed MoSR-b Existing Practice MoSR-b

Price of Essential Products Does Not Change Frequently

Increase in Prices of Essential Items at Regular Intervals that is Insignificant for Consumers

Essential Products are Mostly FMCG Products. Thus, Makes it Difficult to Sell Store/Private Brand that Would Yield Higher Gross Margins

Non-FMCG Categories such as Softlines and Hardlines also Consists of Essential Products

Table 3: Comparing existing practice of B\&M retailers in the $\mathbf{P 3}$ group vis-à-vis proposed MoSR-b Existing Practice

\section{MoSR-b}

Offering Discounts on Essential Products is Not

Affordable Owing to Lower Intake Margins

Discount Offers on Essential Products Must Not be Evaluated in Isolation. They Need to be Evaluated at Overall Consumer-Level Transaction Values

Advertising About New/Latest Products is Advertisement on Essential Products Attractive

Availability is More Productive

Discount Offers on Essential Products Designed and Controlled Centrally Due to Lower Intake Margins

Discount Offers on Essential Products Must be

Decentralized and Aligned with Consumer's Real-Time Needs on Deals

Short-Term Offers/Promotions

Long-Term Offers/Promotions that are Fixed

Table 4: Comparing existing practice of B\&M retailers in the $\mathbf{P 4}$ group vis-à-vis proposed MoSR-b

\section{Existing Practice}

Larger Store Size Enables Better Store Image

Stores in Shopping Mall Location Generate Higher Revenue and Create Premium Store Perception

Stores in Tier-1 Cities Generate Higher Revenue and Create Premium Store Perception

\section{MoSR-b}

Smaller Store Size with Efficient Display Density Enables Higher Productivity without Affecting Store Image

Standalone Stores in High-Street and Institutional Stores Generate Higher Number of Repeat Consumers and Create Convenient Location Perception

Stores in Tier-2 and Tier-3 Cities are Economical and Create Perception of Special/Organized Store in a Small City 
Larger Store, Premium Location, and Bigger City Create Higher-Level of Revenue
Smaller Store, Convenient Location, and Smaller City Create Higher-Level of Economical Safety and Long-Term Sustainability

Corroborating with our observations that the retailers are practicing exactly the opposite of the proposed MoSR-b framework, a majority of them started sacking sales personnel in the stores to avoid financial losses that are in reality an insignificant cost to a retailer in the overall cost-structure of B\&M retailing! as these retailers simply cannot do anything about other retailing costs as they have failed to develop a margin of safety.

Table 5: Comparing existing practice of B\&M retailers in the $\mathbf{P 0}$ group vis-à-vis proposed MoSR-b

\section{Existing Practice}

Output-Driven Measures Evaluate Sales

Personnel Capabilities

Sales Personnel Must Focus on Enhancing

Transaction Value

Sales Personnel Cannot be Empowered to Make Decisions as they Lack Managerial Skills

Higher Number of Sales Personnel in a Store Increases Employee Cost

Sales Personnel with Specialized Skills Generate Higher Revenue

Sales Personnel Cost of Attrition is Negligible

Overall Organizational Structure Must be NonSales and Stores Operation Oriented

Digital, Social Media, and Outdoor Advertisements are Most Attractive Tools of Consumer Communication

\section{MoSR-b}

Inputs-Driven Measures Motivate Sales Personnel to Demonstrate their Real Potential

Sales Personnel Must Focus on Enhancing Consumer Lifetime Value

Sales Personnel Must have Well-Defined and Systematically Controlled Empowerment to Make Real-Time Decisions

Sufficient Number of Sales Personnel in a Store Reduces the Number of Unattended and Unsatisfied Consumers

All-Rounder Sales Personnel are Efficient and Economical

Sales Personnel Attrition Could also Cause Consumer Attrition

Overall Organizational Structure Must be Sales and Stores Operation Oriented

In-Store Engagement with Consumers by the Sales Personnel and Essential Products Rage is the Most Efficient and Economical Strategy of Consumer Communication

\section{DISCUSSION AND CONCLUSION :}

The $\mathrm{B} \& \mathrm{M}$ retailers in India are constantly devoting their time and money in adopting retailing theories, models, and frameworks that are practiced in developed countries that have matured markets and consumers. We believe the Indian market and consumers are moving towards the same maturity levels, but it is still a long way to go. Indian consumers in addition to expecting world-class overall store-image, yet require retailers to facilitate honest and authentic human-led engagement [75]. It is observed that a majority of B\&M retailers in India assume; a) existing category mix is ideal for their stores, b) any modification in the existing category mix could lead to loss of sale of an existing category, $c$ ) it is preferred to have categories generating higher average transaction values, $d$ ) essentials products categories with lower average selling price products and generating lower average transaction values negatively impact store's revenue, e) it is difficult to compete with Online stores over the discount component of selling proposition, f) consumers know what they need and what they should buy and from where they should buy, g) it is easier to evaluate sales personnel performance using output-driven measures, $h$ ) larger stores enable them to provide better shopping experience, i) stores located in Shopping Malls and Tier-1 cities generates higher revenue and create a premium store perception, $\mathrm{j}$ ) getting the best out of a consumer in his/her visit to a store is necessary as the repeat visit is unknown, $\mathrm{k}$ ) developing all-rounder sales personnel is difficult, 1) practicing homedelivery is an additional cost and so on. Such assumptions/misconceptions and widely followed 
practice have created a predisposition and mindset that always distract them from focussing on elements capable of demonstrating a higher probability of developing $\mathrm{MoS}$ for the retailer.

Extending the concept of MoS to B\&M retailing in India is truly complex and multiple experiments involved in developing the proposed MoSR-b framework made us strongly believe that complexity is necessary to an adequate description of an MoS concept in the context of B\&M retailing in India. We hope that the proposed MoSR-b framework will provide new and noteworthy insights into the MoS concept for B\&M retailing in India, and lay a foundation for new directions to guide future research concerning MoS for B\&M retailing.

The main limitation of this study is the coverage of various stakeholders viz., the number of B\&M retailers, product categories, consumer groups, employees, organizational forms, and price positioning while developing the MoSR-b framework. The second limitation would be that the empirical validation is restricted to some $B \& M$ retailers selected for the study and hence the generalizability of the findings and suggestions to other B\&M retailers in India. However, it provides significant inputs regarding adopting the MoS concept to B\&M retailers in India as we have rigorously pursued multiple experiments, empirical evaluations, qualitative explorations over 36 months in addition to incorporating elements from proven theories in the literature that are relevant in the Indian context.

Finally, we urge B\&M retailers in India that the key to success is in identifying who is closer to the market and the consumers which in this case is the Store and Sales Personnel in addition to identifying products that are needed for consumers more frequently which in this case is Essential Products. Once you have identified essential products across the merchandise assortment in the store ensure that the entire retail organization allocates a significant portion of efforts towards promoting these products and attempt to position as an essential store in consumer's minds.

\section{REFERENCES:}

[1] Graham, B., \& Dodd, D. L. F. (2005). Security analysis: The classic 1951 edition. McGraw-Hill Professional.

[2] Klarman, S. A. (1991). Margin of safety - Risk-Averse Value Investing Strategies for the Thoughtful Investor. New York, NY: Harper Business.

[3] Burr, A., \& Cheatham, J. (1995). Mechanical Design and Analysis, 2nd edition, Section 5.2. Prentice-Hall.

[4] Juvinall, R. C. (1967). Engineering Considerations of Stress. Strain, and Strength. McGraw-Hill.

[5] Ramsey, J. K. (2019). Calculating Factors of Safety and Margins of Safety From Interaction Equations. NASA/TM-2019-220153. Available in electronic form at http://www.sti.nasa.gov/ and http://ntrs.nasa.gov/.

[6] Lowe, E. S., \& Lertora, J. J. (2012). Chapter 20 - dose-effect and concentration-effect analysis. In Huang, S. M., Lertora, J. J., Markey, S. P., \& Atkinson Jr, A. J. (Eds.) Principles of clinical pharmacology. Academic Press, pp. $343-356$.

[7] https://www2.deloitte.com/content/dam/Deloitte/in/Documents/consumer-business/in-consumerRLS-2019-noexp.pdf. Retrieved in September 2020.

[8] https://www.ibef.org/industry/retail-india.aspx. Retrieved in September 2020.

[9] Borden, N. H. (1965). The Concept of the Marketing Mix. In G. Schwartz (ed), Science in Marketing (pp. 386-397). New York: John Wiley \& Sons.

[10] McCarthy, E. J. (1960). Basic Marketing: A Managerial Approach. Homewood (Illinois): Richard D. Irwin.

[11] Möller, K. (2006). The Marketing Mix Revisited: Towards the 21st Century Marketing by E. Constantinides. Journal of Marketing Management, 22(3), 439-450.

[12] Popovic, D. (2006). Modelling the Marketing of High-Tech Start-Ups. Journal of Targeting, Measurement and Analysis for Marketing, 14(3), 260-276. 
[13] Gummesson, E. (1994). Making Relationship Marketing Operational. International Journal of Service Industry Management, 5(5), 5-20.

[14] Sriram, V., \& H. J. Sapienza. (1991). An empirical investigation of the role of marketing for small exporters. Journal of Small Business Management, 29(4): 33-43.

[15] Kotler, P. (1984). Marketing Management: Analysis, Planning and Control (5th ed.). New Jersey: Prentice-Hall.

[16] Ohmae, K. (1982). The Mind of the Strategist: The Art of Japanese Business. New York: McGrow-Hill Inc.

[17] Robins, F. (1991). Four Ps or Four Cs or Four Ps and Four Cs. Paper Presented at MEG Conference.

[18] Vignali, C., \& Davies, B. J. (1994). The Marketing Mix Redefined and Mapped - Introducing the MIXMAP Model. Management Decision, 32(8), 11-16.

[19] Doyle, P. (1994). Marketing Management and Strategy. Prentice Hall.

[20] Bennett, A. R. (1997). The Five Vs - A Buyers Perspective of the Marketing Mix. Marketing Intelligence \& Planning, 15(3), 151-156.

[21] Yudelson, J. (1999). Adapting McCarthy's Four Ps for the Twenty-First Century. Journal of Marketing Education, 21(1), 60.

[22] Schultz, D. E. (2001). Marketers: Bid Farewell To Strategy Based on Old 4Ps. Marketing News, $35(2), 7$.

[23] Lauterborn, B. (1990). New Marketing Litany: Four Ps Passé: C-Words Take Over. Advertising Age, 61(41), 26-36.

[24] Rosenberg, L., \& Czepiel, J. (1992). A Marketing Approach to Consumer Retention. Journal of Consumer Marketing, 59, 58-70.

[25] Gummesson, E. (1997). Relationship Marketing as a Paradigm Shift: Some Conclusions From the 30R Approach. Management Decision, 35(4), 267-272.

[26] Grönroos, C. (1994). From Marketing Mix to Relationship Marketing: Towards A Paradigm Shift in Marketing. Management Decision, 32(2), 4-20.

[27] Goldsmith R. E. (1999). The Personalised Marketplace: Beyond the 4Ps. Marketing Intelligence and Planning, 17(4), 178-185.

[28] Patterson, G. P., \& Ward, T. (2000). Relationship Marketing and Management, Handbook Services Marketing and Management. Sage Publications Inc, 416.

[29] Healy, M., Hastings, K., Brown, L., \& Gardiner, M. (2001). The Old, The New and the Complicated - A Trilogy of Marketing Relationships. European Journal of Marketing, 35(1/2), 182-193.

[30] Booms B. H., \& Bitner B. J. (1980). Marketing strategies and organisation structures for service firms. In Donnelly, J., \& George W. R. (Eds.), Marketing of services. American Marketing Association, 47-51.

[31] Cowell, D. W., \& Communication Advertising. (1984). The marketing of services. London: Heinemann.

[32] Brunner, G. C. (1989). The Marketing Mix: Time for Reconceptualization. Journal of Marketing Education, 11(2), 72-77.

[33] Rushton, A., \& Carson, D. J. (1989). Services - Marketing with A Difference? Marketing Intelligence and Planning, 7(5/6), 12-17. 
[34] Fryar, C. R. (1991). What's Different About Services Marketing? The Journal of Marketing Services, 5(4), 53-58.

[35] Heuvel, J. (1993). Diensten Marketing (Services marketing). The Netherlands Wolters-Noordhoff Groningen.

[36] Doyle, P. (1994). Marketing Management and Strategy. Prentice Hall.

[37] Melewar, T. C., \& Saunders, J. (2000). Global Corporate Visual Identity Systems: Using an Extended Marketing Mix. European Journal of Marketing, 34(5/6), 538-550.

[38] English, J. (2000). The Four Ps of Marketing are Dead. Marketing Health Services, 20(2), 20-23.

[39] Grove, S. J., Fisk, R. P., \& John, J. (2000). Service as Theater, Guidelines and Implications, Handbook Services Marketing and Management. Sage Publications Inc, 25.

[40] Beckwith, H. (2001). The Invisible Touch - The Four Keys of Modern Marketing. Texere Publishing.

[41] Ster, V. D. W. (1993). Marketing En Detailhandel (Marketing and Retailing). The Netherlands: Groningen, Wolters-Noordhoff, 328.

[42] Boekema, J. J., Bueren Van, E. B, Lobstein, S., Oosterhuis, A., \& Schweitzer, P. (1995). Basisboek Marketing (Basic Book of Marketing), NL: Derde druk, Groningen, WoltersNoordhoff.

[43] Mulhern, F. J. (1997). Retail Marketing: From Distribution to Integration. International Journal of Research in Marketing, 14(2), 103-124.

[44] Wang, F., Head, M., \& Archer, N. (2000). A Relationship-Building Model for The Web Retail Marketplace. Internet Research: Electronic Networking Applications and Policy, 10(5), 374-384.

[45] Kotler, P. (2003). Marketing Management (11th ed.). Prentice Hall International Editions.

[46] Turnbull P., Ford, D., \& Cunningham, M. (1996). Interaction, Relationships and Networks in Business Markets: An Evolving Perspective. Journal of Business \& Industrial Marketing, 11(3/4), 44-62.

[47] Davis W., \& Brush, K. E. (1997). High-Tech Industry Marketing: The Elements of a Sophisticated Global Strategy. Industrial Marketing Management, 26(1), 1-13.

[48] Parasuraman, A. (1998). Customer Service in Business-to-Business Markets: An Agenda for Research. The Journal of Business and Industrial Marketing, 13(4), 309-321.

[49] Andersen, J. C., \& Narus J. A. (1999). Business Market Management, Understanding, Creating and Delivering Value. New Jersey. Prentice Hall.

[50] Peattie, K. (1997). The Marketing Mix in the Third Age of Computing. Marketing Intelligence \& Planning, 15(3), 142-150.

[51] Levy, M., \& Weitz, B. A. (2008). Retailing Management. Fifth Edition, Fourteenth reprint, Tata McGraw Hill. 362 - 395.

[52] Berman, B., \& Evans, J. R. (2009). Retail Management. Tenth Edition, Third impression, Pearson Prentice Hall. 407 - 436.

[53] Ganesha, H. R., Aithal, P. S., \& Kirubadevi, P. (2020). Integrated Inventory Management Control Framework. International Journal of Management, Technology, and Social Sciences (IJMTS), 5(1), 147-157.

[54] Ganesha, H. R., Aithal, P. S., \& Kirubadevi, P. (2020). Optimal Category Mix in MultiCategory Retailing - Insights from an Experiment. International Journal of Case Studies in Business, IT, and Education (IJCSBE), 4(1), 112-126. 
[55] Ganesha, H. R. \& Aithal, P. S. (2020). Retailing Performance Evaluation Scale for Indian Brick-and-Mortar Lifestyle Retailers (LSRS-b). International Journal of Applied Engineering and Management Letters (IJAEML), 4(1), 303-322.

[56] Homburg, C., Hoyer, W. D., \& Koschate, N. (2005). Customers' reactions to price increases: do customer satisfaction and perceived motive fairness matter?. Journal of the Academy of Marketing Science, 33(1), 36-49.

[57] Ganesha, H. R., Aithal, P. S., \& Kirubadevi, P. (2020). Changes in Consumer Perspective towards Discount at Brick-and-Mortar Stores owing to Emergence of Online Store Format in India. International Journal of Management, Technology, and Social Sciences (IJMTS), 5(1), 43-83.

[58] Ganesha, H. R. Aithal, P. S., \& Kirubadevi, P. (2020). Long-Term Discounting Frameworks: Insights from Multiple Experiments. International Journal of Management, Technology, and Social Sciences (IJMTS), 5(1), 84-100.

[59] Ganesha, H. R., Aithal, P. S., \& Kirubadevi, P. (2020). Decentralized Discounting Framework: Insights from an Experiment. International Journal of Applied Engineering and Management Letters (IJAEML), 4(1), 20-40.

[60] Ganesha, H. R., Aithal, P. S., \& Kirubadevi, P. (2020). Short-Term Discounting Frameworks: Insights from Multiple Experiments. International Journal of Case Studies in Business, IT, and Education (IJCSBE), 4(1), 8-22.

[61] Ganesha, H. R., Aithal, P. S., \& Kirubadevi, P. (2020). Integrated Discounting Framework for Indian Brick-and-Mortar Retailers. International Journal of Management, Technology, and Social Sciences (IJMTS), 5(1), 110-123.

[62] Ganesha, H. R., Aithal, P. S., \& Kirubadevi, P. (2020). Impact of Store Size Reduction on Overall Store Performance - Insights from an Experiment. International Journal of Case Studies in Business, IT, and Education (IJCSBE), 4(1), 103-111.

[63] Ganesha, H. R., Aithal, P. S., \& Kirubadevi, P. (2020). Ideal Store Locations for Indian Retailers - An Empirical Study. International Journal of Management, Technology, and Social Sciences (IJMTS), 5(1), 215-226.

[64] https://www.mckinsey.com/featured-insights/urbanization/urban-awakening-in-india. Retrieved in September 2020.

[65] Ganesha, H. R., Aithal, P. S., \& P, Kirubadevi, P. (2020). Consumer Affordability in Tier-1, Tier2, and Tier-3 Cities of India - An Empirical Study. International Journal of Applied Engineering and Management Letters (IJAEML), 4(1), 156-171.

[66] Ganesha, H. R. \& Aithal, P. S. (2020). Organizing the Unorganized Lifestyle Retailers in India: An Integrated Framework. International Journal of Applied Engineering and Management Letters (IJAEML), 4(1), 257-278.

[67] Ganesha, H. R., Aithal, P. S., \& Kirubadevi, P. (2020). Input and Output Driven Sales Personnel Performance Measures: Insights from an Experiment. International Journal of Case Studies in Business, IT, and Education (IJCSBE), 4(1), 23-37.

[68] Ganesha, H. R., Aithal, P. S., \& Kirubadevi, P. (2020). Need-Based Sales Pitch: Insights from an Experiment. International Journal of Case Studies in Business, IT, and Education (IJCSBE), 4(1), 79-87.

[69] Ganesha, H. R. \& Aithal, P. S. (2020). Inappropriate Adaptation of Information Communication and Computation Technologies (ICCT) by Indian Brick-and-Mortar Lifestyle Retailers - Insights from an Experiment. In Information Communication and Computation Technologies - The Pillar of Transformation. New Delhi Publishers, India. 
[70] Ganesha, H. R., Aithal, P. S., \& Kirubadevi, P. (2020). An Integrated Framework to Derive Optimal Number of Sales Personnel for a Retail Store. International Journal of Applied Engineering and Management Letters (IJAEML), 4(1), 41-50.

[71] Ganesha, H. R. \& Aithal, P. S. (2020). Sales Personnel Training - An Integrated Framework for Indian Brick-and-Mortar Retailers. International Journal of Case Studies in Business, IT, and Education (IJCSBE), 4(1), 172-187.

[72] Ganesha, H. R. \& Aithal, P. S. (2020). Rational Organizational Structure: For Brick-and-Mortar Lifestyle Retailers in India to Overcome Diseconomies of Scale and Protect Firm's Sustainability (ROLS-b). International Journal of Management, Technology, and Social Sciences (IJMTS), 5(2), 42-61.

[73] Ganesha, H. R. \& Aithal, P. S. (2020). Sales Personnel Attrition Control and Retention - An Integrated Framework for Retailers in India (RSPR-LS). International Journal of Applied Engineering and Management Letters (IJAEML), 4(2), 78-95.

[74] Ganesha, H. R. \& Aithal, P. S. (2020). Consumer Communication Deployment Tactics: An Integrated Framework for Lifestyle Brands and Retailers in India (CCF-LS). International Journal of Applied Engineering and Management Letters (IJAEML), 4(2), 1-21.

[75] Ganesha, H. R. \& Aithal, P. S. (2020). Theory of Brick-and-Mortar Retailing in India (ToR-b). International Journal of Management, Technology, and Social Sciences (IJMTS), 5(2), 116-132. 